\title{
Investigation of Turbulence Parameters Influence on Results of CFD Modeling of Flow in Ultrasonic Flowmeter
}

\author{
Vitalii Roman ${ }^{*}$, Fedir Matiko, Igor Kostyk \\ Lviv Polytechnic National University, S. Bandery St., 12, Lviv, 79013, Ukraine
}

Received: April 16, 2021. Revised: June 08, 2021. Accepted: June 15, 2021.

(C) 2021 The Authors. Published by Lviv Polytechnic National University.

\begin{abstract}
The article investigated the influence of turbulence parameters of the SolidWorks Flow Simulations CFD package on the results of flow simulation in a two-path ultrasonic flowmeter. It has been found that the main turbulence parameters of SolidWorks Flow Simulations (turbulence intensity, turbulence length, turbulence energy and turbulence dissipation) slightly affect the result of the flow simulation in a full-filled pipeline of circular profile without additional turbulous elements (turbine, rotor, other). In view of this, during the CFD modeling of the flow measurement process using ultrasonic flowmeters, it is recommended to apply turbulence parameters installed in the SolidWorks Flow Simulations CFD package by default. At the same time, the time consumed by the computer to perform CFD modeling is almost unchanged when the specified parameters of the SolidWorks Flow Simulations CFD package.
\end{abstract}

Keywords: CFD modeling; ultrasonic flowmeter; turbulence parameters; flow.

\section{The goal of the study and review of scientific works}

The modern level of development of computational fluid dynamics methods (Computational Fluid Dynamics in the future, simply CFD modeling) allows you to solve a wide range of scientific and practical problems, in particular in the field of ultrasound flowmeter [1]-[5]. One of the computer CFD applications that implement the methods of computational fluid dynamics are SolidWorks Flow Simulations. Examples of SolidWorks Flow Simulations flow analysis and problem solving ultrasonic flow meter shown in scientific studies [6]-[7]. To execute the flow analysis in SolidWorks Flow Simulations, the user needs to perform a clear algorithm (see Fig.1), which, in particular, contains settings of Flow Simulations settings ("Setting Up a SolidWorks Flow Simulation Project" in Fig.1) [8]. In turn, the settings of Flow Simulations are selected by choosing their values from the list of possible ones (see Table 1).

One of the parameters to be configured is the parameters of turbulence. The problem that occurs is that the user can choose the parameters of both default and "introduce their own values of these parameters, if they are confident" [8], [9]. In this case, in the SolidWorks Flow Simulations reference materials, namely in the "Turbulence Parameters" section, there is no range of possible values of these parameters, as well as how the results of the analysis are changed in various variants of turbulence parameters [8], [9]. Therefore, in this article, the authors are facilitated by the influence of the difference in the parameters of the turbulence of SolidWorks Flow Simulations 2010 on the results of modeling the process of measuring the expenditure of an ultrasonic flowmeter (USM). The results of this work will serve as a logical continuation of the preliminary investigated authors in this area presented, in particular in [10].

${ }^{*}$ Corresponding author. Email address: roman.vitaliycfd@ gmail.com

This paper should be cited as: V. Roman, F. Matiko, I. Kostyk. Investigation of turbulence parameters influence on results of CFD modeling of flow in ultrasonic flowmeter. Energy Engineering and Control Systems, 2021, Vol. 7 , No. 1, pp. 73 - 78. https://doi.org/10.23939/jeecs2021.01.073 


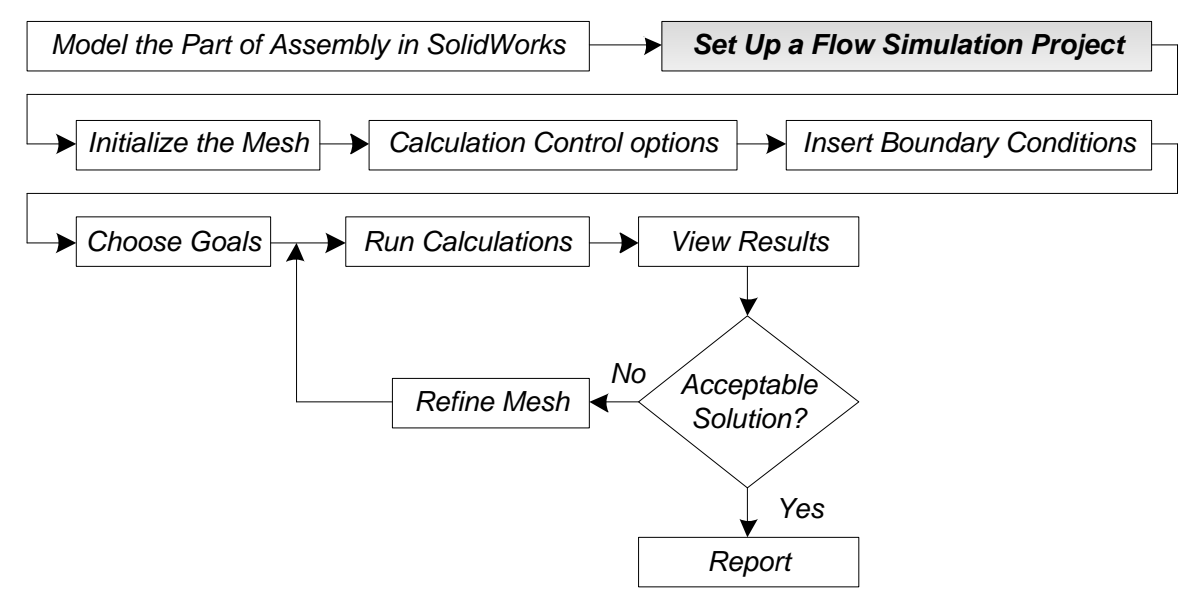

Fig.1. Algorithm for analysis of flows in SolidWorks Flow Simulations [8].

Table 1. List of different general settings in SolidWorks Flow Simulation [8].

\begin{tabular}{|l|l|}
\hline \multicolumn{1}{|c|}{ Name of parameter } & \multicolumn{1}{c|}{ Options } \\
\hline \hline Analysis type & Internal, External \\
\hline Physical Features & Heat Conduction in Solids, Radiation, Time-dependence, Gravity, Rotation \\
\hline Fluids & Gases, Liquids, Non-Newtonian Liquids, Compressible Liquids, Real Gases, Steam \\
\hline Flow Types & Laminar, Laminar and Turbulent, Turbulent \\
\hline Solids & Alloys, Glasses and Minerals, Metals, Non-isotropic Solids, Polymers, Semiconductors \\
\hline Wall Thermal Condition & Adiabatic Wall, Heat Flux, Heat Transfer Rate, Temperature \\
\hline Thermodynamic Parameters & Pressure, Temperature, Density \\
\hline Velocity Parameters & Velocity in X direction, Velocity in Y direction, Velocity in Z direction \\
\hline Turbulence Parameters & Turbulence Intensity, Turbulence Length, Turbulence Energy, Turbulence Dissipation \\
\hline
\end{tabular}

\section{Main material}

Modeling flow in SolidWorks Flow Simulations is performed on the results of solutions of systems of NavierStokes equations. In this case, there is a possibility of modeling both laminar and turbulent flows. Since the majority of fluid flows encountered in engineering practice is turbulent, so the modeling of such flows received special attention. To predict turbulent flows, the Favre-averaged Navier-Stokes equations are used, where time-averaged effects of the flow turbulence on the flow parameters are considered, whereas the other, i.e. large-scale, time-dependent phenomena are taken into account directly. Through this procedure, extra terms known as the Reynolds stresses appear in the equations for which additional information must be provided. To close this system of equations, Flow Simulation employs transport equations for the turbulent kinetic energy and its dissipation rate, the so-called $k-\varepsilon$ model [9].

The turbulence parameters of SolidWorks Flow Simulations include [8], [9]:

1) turbulent intensity (TI);

2) turbulent length (TL);

3) turbulent energy (TE);

4) turbulent dissipation (TD).

By default, these parameters have values listed in Table 2. In this case, the user must choose one of the corresponding pairs of turbulence parameters (TI-TL or TD-TE), which can be customized as needed. Other important parameters for setting up SolidWorks Flow Simulations include: type environment - air; inlet mass flow rate $0.1 \mathrm{~kg} / \mathrm{s}$; outlet static pressure; $101325 \mathrm{~Pa}$; level of initial mesh -6 .

Table 2. Turbulence parameters of SolidWorks Flow Simulations 2010 (default).

\begin{tabular}{|c|c|c|c|}
\hline $\begin{array}{c}\text { Turbulent intensity, } \\
I, \%\end{array}$ & $\begin{array}{c}\text { Turbulent length, } \\
l, \mathrm{~m}\end{array}$ & $\begin{array}{c}\text { Turbulent energy, } \\
k, \mathrm{~J} / \mathrm{kg}\left(\mathrm{m}^{2} / \mathrm{s}^{2}\right)\end{array}$ & $\begin{array}{c}\text { Turbulent dissipation, } \\
\varepsilon, \mathrm{W} / \mathrm{kg}\left(\mathrm{m}^{2} / \mathrm{s}^{3}\right)\end{array}$ \\
\hline \hline 2 & $\begin{array}{c}\text { depending on the characteristic size of } \\
\text { 3D-model }\end{array}$ & 1 & 1 \\
\hline
\end{tabular}


CFD modeling, the results of which are given in this work, was performed on a personal computer HP ProBook 4540s with the following specifications: CPU (Intel (R) Core (TM) I5-2450M CPU, 2.50 GHz, 2 Active Kernels, 4 logical processors), Memory (DDR3, 6.0 GB), video system (Intel HD Graphics 3000 (GT2 +), 2108 MB).

Let us consider the effect of the variation of the turbulence parameters of SolidWorks Flow Simulations on the results of modeling the mass flow rate in the stream part of a three-dimensional model of a two-path chordal USM. Thus, the model of USM is installed at a distance of $2 \mathrm{D}$ after the local fitting " $90^{\circ}$ bend" (see Figure 2).

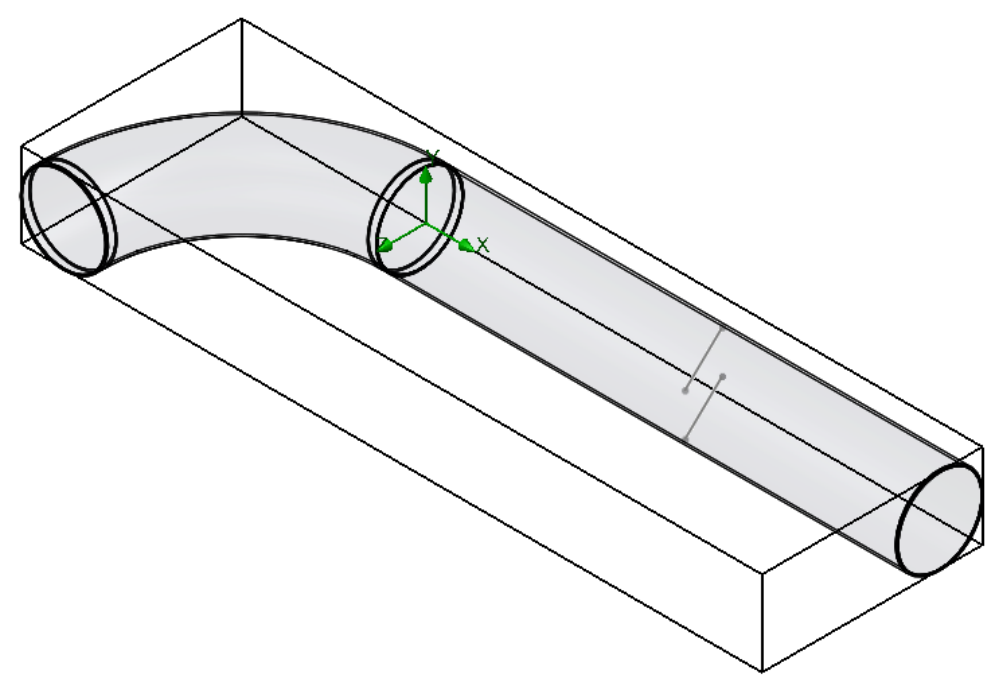

Fig.2. Three-dimensional model of measuring pipeline with USM after local fitting " $90^{\circ}$ bend"

The paper used equation calculating of USM mass flow rate that has the form [11]:

$$
q_{m_{-} C F D}=\frac{\pi d^{2}}{4} \cdot \frac{\sum_{i=1}^{N} u_{C F D}(i) \cdot \rho_{C F D}(i)}{N},
$$

where $u_{C F D}(i), \rho_{C F D}(i)$ are average flow velocity and flow density along the $i$-th acoustic path of the USM according to the results of CFD modeling; $N$ is number of acoustic path of USM $(N=2) ; d$ is internal diameter of the measuring pipeline.

\subsection{Turbulent intensity}

Turbulence intensity or level of turbulence is determined by the formula [12], [13]:

$$
I=\frac{u^{\prime}}{U}
$$

where $u^{\prime}$ is mean turbulent velocity fluctuations; $U$ is average flow velocity (averaged by Reynolds).

When setting the boundary conditions for CFD modeling, it is often necessary to estimate the turbulence intensity at the input of a three-dimensional model. To do this accurately, we need to have good measurement results or previous experience. Here are some examples of general estimates of the turbulence intensity [12], [13]:

1) Cases of high turbulence: high-speed stream in complex geometry, such as heat exchangers and rotating machines (turbines and compressors). In such cases, the turbulence intensity is usually from 5 to $20 \%$.

2) Cases of medium turbulence: flow in not very complex geometry, such as large pipes, ventilation channels, or low-speed streams (small numbers of Reynolds). In such cases, the turbulence intensity is usually from 1 to $5 \%$.

3) Cases of low turbulence: streams with almost zero speed. In such cases, the turbulence intensity is very low, much lower than $1 \%$. 
For flow in the middle of pipelines, turbulence intensity at a certain point (e.g. USM installation location) depends entirely on the story flow upstream. If the flow upstream is underdeveloped and undistorted, we can use low turbulence intensity. If the flow is fully developed, the turbulence intensity can reach several percent. Turbulence intensity in the core of fully developed flow can be estimated using the following formula obtained from empirical correlations for flow in a pipe $[12,13]$ :

$$
I=0.16 \operatorname{Re}^{-\frac{1}{8}}
$$

where Re - Reynolds number based on the hydraulic diameter pipe. In the case of circular pipe cross section of stream discharge (completely filled with liquid) hydraulic diameter is equal to the geometric $(d)$. For example, when $\operatorname{Re}=50000$, the turbulence intensity by formula (3) will be approximately $4 \%$.

The results of modeling the USM mass flow at different values of the turbulence intensity are given in Table 3.

Table 3. Influence of turbulence intensity on the results of CFD modeling.

\begin{tabular}{|c|c|c|c|}
\hline Turbulence model & Turbulent intensity, $\%$ & $q_{m_{-} \text {CFD }}, \mathrm{kg} / \mathrm{s}$ & Duration modeling, min \\
\hline \hline TI-TL & $\begin{array}{c}2 \\
\text { (default) }\end{array}$ & 0.0985759579732537 & 3.15 \\
\hline TI-TL & $\begin{array}{c}3.9 \\
\text { (by formula (3)) }\end{array}$ & 0.0985751182280160 & 3.14 \\
\hline TI-TL & 5 & 0.0985767454545064 & 3.18 \\
\hline TI-TL & 20 & 0.0985766655811975 & 3.11 \\
\hline TI-TL & 10 & 0.0985767636213398 & 3.34 \\
\hline
\end{tabular}

\subsection{Turbulent length}

Turbulent length is a physical quantity related to the size of large turbulence that contains energy in turbulent flows. It is often used to evaluate the turbulent flow properties during CFD modeling. Turbulent length should not exceed geometrical dimensions of the cross section of the pipeline (to be larger than the inner diameter of the pipe) [9], [13].

In the $k-\varepsilon$ model of turbulence length can be calculated according to the following formula [12], [13]:

$$
l=\frac{C_{\mu} k^{3 / 2}}{\varepsilon},
$$

where $k$ is kinetic energy of turbulence; $\varepsilon$ is dissipation of kinetic energy of turbulence; $C_{\mu}$ is constant, which in the standard $k-\varepsilon$ model of turbulence is equal to 0.09 [9], [13].

Some CFD applications (for example, Fluent, Phoenics, CFD-ACE and others) use the formula to determine the turbulent length that is based on the mixing length [12]. This means that the value of the turbulent length in these CFD applications is approximately twice as much as others.

For flows in pipes with a cylindrical cross-section, the turbulence length can be assessed by the pipe hydraulic diameter. In fully developed flow turbulence the length is $\sim 3.8 \%$ of the pipe hydraulic diameter. Hence [12]:

$$
l=0.038 d
$$

For CFD applications that determine the turbulence length based on the mixing length (for example, the mentioned Fluent, Phoenics, CFD-ACE and others), a replacement of 0.038 (3.8\%) in formula (5) is replaced by 0.07 (7\%). The coefficient of 0.07 thus corresponds to the maximum value of stirring in a fully developed turbulent pipe flow. Hence [12]:

$$
l=0.07 d
$$


It should be noted that the above ratio between the turbulence length and internal pipeline diameter is not used in all situations. However, in most cases, this approximation is true.

When the inlet flow is bounded by walls with turbulent boundary layers, the turbulence length scale can be estimated (approximately) from the inlet boundary layer thickness. Set turbulence length to 0.22 of the inlet boundary layer thickness. For CFD applications using a turbulence length based on the mixing-length, we use 0.4 of the inlet boundary layer thickness [12], [13].

The results of modeling the USM mass flow at different turbulence length values are given in Table 4.

Table 4. Influence of turbulence lengths on the results of CFD modeling.

\begin{tabular}{|c|c|c|c|}
\hline Turbulence model & Turbulent length, $\mathrm{m}$ & $q_{m_{-} \text {CFD }}, \mathrm{kg} / \mathrm{s}$ & Duration modeling, min \\
\hline \hline TI-TL & $\begin{array}{c}0.00104 \\
\text { (default) }\end{array}$ & 0.0985759579732537 & 3.15 \\
\hline TI-TL & $\begin{array}{c}0.0038 \\
\text { (by formula (5)) }\end{array}$ & 0.0985717780624039 & 3.34 \\
\hline TI-TL & $\begin{array}{c}0.007 \\
\text { (by formula (6)) }\end{array}$ & 0.0985726091696936 & 3.21 \\
\hline
\end{tabular}

\subsection{Turbulence (kinetic) energy}

We understand the turbulence energy as the amount of kinetic energy per unit mass of turbulent fluctuations in the turbulent flow. The exact definition of this parameter as the initial condition for CFD modeling is important for high-quality flow modeling, especially with high numbers of Reynolds. The formula for determining the turbulence energy for smooth pipes is presented below [12], [13]:

$$
k=\frac{3}{2}(U I)^{2},
$$

where $I$ is initial turbulence intensity; $U$ is initial flow velocity.

The results of modeling the USM mass flow at different turbulence energy values are given in Table 5.

Table 5. Influence of turbulence energy on the results of CFD modeling.

\begin{tabular}{|c|c|c|c|}
\hline Turbulence model & Turbulent energy, $\mathrm{m}^{2} / \mathrm{s}^{2}$ & $q_{m_{-} \text {CFD }}, \mathrm{kg} / \mathrm{s}$ & Duration modeling, min \\
\hline \hline TD-TE & 1 & 0.0985755152736247 & 3.18 \\
\hline TD-TE & $\begin{array}{c}0.0670492517673341 \\
\text { (by formula (7)) }\end{array}$ & 0.0985751743489322 & 3.80 \\
\hline
\end{tabular}

\subsection{Turbulent dissipation}

Dissipation (scattering) of turbulence is a speed with which the kinetic energy of turbulence is converted into thermal internal energy [13]. The formula for determining the turbulence dissipation is given below [12, 13]:

$$
\varepsilon=C_{\mu}^{\frac{3}{4}} k^{\frac{3}{2}} l^{-1}
$$

where $k$ must be calculated by the formula (7), the value of the coefficient $C_{\mu}=0.09$, and the value of the turbulence length should be determined by the formula (5). By applying the indicated approaches, the value of turbulence dissipation is obtained 0.000574068 .

The results of modeling the USM mass flow at different turbulence dissipation values are given in Table 6.

Table 6. Influence of turbulence dissipation on the results of CFD modeling.

\begin{tabular}{|c|c|c|c|}
\hline Turbulence model & Turbulent energy, $\mathrm{m}^{2} / \mathrm{s}^{2}$ & $q_{m_{-} \text {CFD }}, \mathrm{kg} / \mathrm{s}$ & Duration modeling, min \\
\hline \hline TD-TE & 1 & 0.0985755152736247 & 3.18 \\
\hline TD-TE & $\begin{array}{c}0.000574068 \\
\text { (by formula (8) })\end{array}$ & 0.0985806410301395 & 3.22 \\
\hline
\end{tabular}




\title{
3. Conclusion
}

According to the modeling results presented in Tables 3-6, variation defined in SolidWorks Flow Simulations options turbulence does not have much effect on the simulation result of turbulent flow in the completely filled circular section pipeline without turbulating elements (turbine, rotor, other). The time consumed by the computer for modeling is also almost unchanged when the turbulence parameters are changed. In view of this, during the CFD modeling of the flow rate measurement process using an ultrasonic flowmeter we recommend using turbulence parameters installed in SolidWorks Flow Simulations by default.

\section{References}

[1] Hilgenstock, A., and Ernst, R. (1996). Analysis of installation effects by means of computational fluid dynamics - CFD vs experiments? Flow Meas. Instrum., 7(3/4), 161-171. https://doi.org/10.1016/S0955-5986(97)88066-1

[2] Zhao, H., Peng, L., Stephane, S.A., Ishikawa, H., Shimizu, K., and Takamoto, M. (2013). CFD Aided Investigation of Multipath Ultrasonic Gas Flow Meter Performance Under Complex Flow Profile. IEEE Sensors Journal, 14(3), 897-907. https://doi.org/10.1109/JSEN.2013.2290863

[3] Barton, N.A., ed. (2002). In-service performance of ultrasonic flowmeters - Application and validation of CFD modelling methods. Technical report no. 2002/72. Glasgow, National Engineering Laboratory. 43 pages.

[4] Staubli, T., Luscher, B., Senn, F., and Widmen, M. (2007, October 14-18). CFD optimized acoustic flow measurement and laboratory verification. Proceedings of international conference "Hydraulics, Water Resources, Coastal and Environmental Engineering, 2007. HYDRO-2007. Granada. 7 pages.

[5] Duffell. C.J., Brown, G.J., Barton, N.A., and Stimpson, B.P. (2003, March 25-28). Using optimization algorithms and CFD to improve performance of ultrasonic flowmeters. Proceedings of $2^{\text {nd }}$ International South East Asia Hydrocarbon Flow Measurement Workshop, 2003. Kuala Lumpur. 16 pages.

[6] Wright, W.M.D., and O’Riordan, S.A. (2009, September 2-4). Characterisation of capacitive ultrasonic transducer gas flow meters. Proceedings of 26th international manufacturing conference, 2009. IMC-2009. Dublin. 207-214.

[7] Songsong Zhang, Baohuan Su, Jianmin Liu, Xuemin Liu, Guoli Qi, and Yajun Ge (2017, December 8-10). Analysis of flow characteristics and flow measurement accuracy of elbow with different diameters. Proceedings of $3^{\text {rd }}$ International Conference on Advances in Energy Resources and Environment Engineering. Harbin, China. Volume 113.

[8] Matsson, J. (2010). An introduction to SolidWorks Flow Simulation 2010. SDC Publications, 297 pages.

[9] SolidWorks Flow Simulation 2012 Technical Reference.

[10] Matiko, F., Roman, V., and Masnyak, O. (2018). Features of configuring CFD-programs to improve the efficiency of the simulation of flowmeters. Automation of Technological and Business Processes, 9(4). https://doi.org/10.15673/atbp.v10i4.827

[11] International Organization for Standardization. (2010). ISO 17089-1: Measurement of fluid flow in closed conduits - Ultrasonic meters for gas. Part 1: Meters for custody transfer and allocation measurement. Geneva, Switzerland: ISO.

[12] ANSYS, Inc. (2018), "ANSYS Fluent User's Guide, Release 19.0".

[13] Wilcox, D.C. (2006). Turbulence Modeling for CFD (Third Edition). DCW Industries, 522 pages.

\section{Дослідження впливу параметрів турбулентності на результати CFD-моделювання потоку в ультразвуковому витратомірі}

\author{
Віталій Роман, Федір Матіко, Ігор Костик \\ Наиіональний університет «Львівська політехніка», вул. С. Бандери 12, Львів, 79013, Украӥна
}

\section{Анотація}

В статті досліджено вплив параметрів турбулентності CFD-пакету SolidWorks Flow Simulations на результати моделювання потоку в двоканальному ультразвуковому витратомірі. Встановлено, що основні параметри турбулентності SolidWorks Flow Simulations (інтенсивність турбулентності, довжина турбулентності, енергія турбулентності та дисипація турбулентності) незначно впливають на результат моделювання потоку у повністю заповненому трубопроводі круглого перерізу без введених додаткових турбулізуючих елементів (турбіна, ротор, інше). Зважаючи на це, під час CFD-моделювання процесу вимірювання витрати потоків за допомогою ультразвукових витратомірів рекомендовано застосовувати параметри турбулентності, встановлені в CFD-пакеті SolidWorks Flow Simulations за замовчуванням. При цьому час, який витрачається комп'ютером на виконання CFD-моделювання, майже не змінюється при зміні зазначених параметрів турбулентності CFD-пакеті SolidWorks Flow Simulations.

Ключові слова: CFD-моделювання; ультразвуковий витратомір; параметри турбулентності; потік. 